\title{
PROBLEMATIKA PENGEMBANGAN KETERAMPILAN MENGAJAR BERBASIS PENDEKATAN SAINTIFIK PADA MAHASISWA PPL REAL TAHUN 2018 JURUSAN PENDIDIKAN BAHASA JEPANG UNDIKSHA
}

\author{
N. K.Y. Dewi ${ }^{1}$, N. M. D.S. Mardani ${ }^{2}$, I.W. Sadyana ${ }^{3}$ \\ Jurusan Pendidikan Bahasa Jepang, \\ Universitas Pendidikan Ganesha \\ Singaraja, Indonesia \\ e-mail: kookieyasinta@gmail.com \\ desakmardani@undiksha.ac.id wayan.sadyana@undiksha.ac.id
}

\begin{abstract}
Abstrak
Penelitian ini bertujuan untuk menganalisis permasalahan yang dihadapi mahasiswa PPL Real Jurusan Pendidikan Bahasa Jepang Undiksha Tahun 2018 dalam melaksanakan penerapan keterampilan berbasis pendekatan saintifik. Jenis penelitian ini adalah deskriptif kualitatif. Metode yang digunakan adalah angket kepada 32 orang dan wawancara kepada 10 orang. Hasil Penelitian ini menunjukkan bahwa kesulitan yang dihadapi mahasiswa PPL Real dalam penerapan keterampilan mengajar berbasis pendekatan saintifik (5M) sebagai berikut. 1) Aspek mengamati yaitu mempersiapkan objek yang digunakan. 2) Aspek menanya yaitu mendorong peserta didik untuk aktif. 3) Aspek mencoba yaitu menerapkan kegiatan pembelajaran yang berorientasi pada hasil yang bisa diukur dan diamati. 4) Aspek mengasosiasi yaitu memfasilitasi peserta didik untuk melakukan proses mengasosiasi. 5) Aspek mengomunikasikan yaitu mengontrol waktu. Komponen yang paling banyak mengalami kesulitan adalah pada aspek mengamati sebanyak $69 \%$ dan yang paling sedikit mengalami kesulitan adalah aspek mengomunikasikan sebanyak $48 \%$.
\end{abstract}

Kata Kunci : Keterampilan Mengajar, Kurikulum 2013, Pendekatan Saintifik

\section{要旨}

本研究の目的は、2018年度ガネシャ教育大学日本語教育学科の教育実習が科学的アプローチ に基づく用問題を明らかにする。調査対象は、2018年度に教育実習32名である。データはイ ンタビュー、アンケートにより収集した。教員として求められる 5 のつスキルの実施に関す る困難は次の通り、1つ目は、「観察」オブジェクトを準備すること、刺激を与えることで ある。2つ目は、「観察」生徒がアクティブになるようにモチベーションを提供すること、 ディスカッションする活動を作成することである。3つ目は、「実験」生徒に明確に指示を 与えること、評価できる活動を実習することである。4つ目は、「関連付け」日本とインド ネシア文化を比較する活動である。5つ目は、「コミュニケーション」教室の活動に関する 時間の管理であることが分かった。

キーワード : 教育スキル、2013年カリキュラム、科学的アプローチ

\section{Pendahuluan}

Kurikulum 2013 merupakan sebuah kurikulum yang mengutamakan pemahaman, keahlian atau keterampilan dan pendidikan karakter (Permatasari, 2014). Sehingga Kurikulum 2013 tidak hanya mengedepankan kemampuan siswa secara akademik, tetapi Kurikulum 2013 ini juga mengutamakan pembangunan karakter siswa dalam lingkungan sekolah, keluarga, dan masyarakat. Hal ini didukung oleh pendapan Mulyasa (2014) yang menyatakan bahwa tujuan Kurikulum 2013 adalah untuk menghasilkan insan yang produktif, kreatif, inovatif, efektif melalui penguatan sikap, keterampilan dan pengetahuan yang terintegrasi. 
Dalam proses pembelajaran, Kurikulum 2013 menggunakan pendekatan saintifik. Pendekatan saintifik merupakan sekumpulan tehnik untuk menyelidiki fenomena, memperoleh pengetahuan baru yang mengoreksi dan mengintegrasikan pengetahuan sebelumnya (Zaim, 2017). Penerapan pendekatan saintifik ini diharapkan mampu digunakan sebagai langkah awal pengembangan sikap, keterampilan serta pengetahuan peserta didik. Pada pendekatan saintifik menekankan pada proses pencarian pengetahuan yang berkenaan dengan materi pembelajaran melalui kegiatan mengamati, menanya, mencoba, mengasosiasikan dan mengkomunikasikan. Dalam keseluruhan kegiatan yang ditekankan dalam Kurikulum 2013, tentunya memiliki perkembangan sesuai dengan refleksi dalam penerapannya.

Kurikulum 2013 Revisi sudah mengintegrasikan Gerakan Literasi Sekolah (GLS), keterampilan abad 21 atau diistilahkan dengan 4C (Creative, Critical thingking, Communicative, dan Collaborative), dan Higher Order of Thingking Skill (HOTS) (Kemendikbud, 2016). Berdasarkan hasil wawancara kepada mahasiswa yang sudah melaksanakan PPL Real, belum semua sekolah dapat menerapkan dengan sempurna, sekolah yang digunakan untuk melaksanakan praktik sebagaian besar masih menerapkan pendekatan saintifik $(5 \mathrm{M})$ pada saat mengajar. Pada beberapa sekolah sudah menerapkan Kurikulum 2013 tetapi tidak menerapkan secara utuh seperti hanya menerapkan Gerakan Literasi Sekolah (GLS) saja sebelum memulai pembelajaran dan menerapkan Keterampilan abad 21 dan HOTS pada beberapa kegiatan belajar. Pada penerapan Kurikulum 2013 revisi pengajar masih mengalami kesulitan. Selain itu menurut pengajar pada kegiatan dalam keterampilan 21 serta HOTS memiliki kemiripan dengan kegiatan pada pendekatan saintifik (5M) sehingga pengajar lebih memilih menggunakan pendekatan saintifik walaupun pada pendekatan ini pengajar juga masih mengalami kesulitan dalam beberapa pelaksanaan kegiatannya. Sehingga tidak dipungkiri juga akan menimbulkan masalah dalam pembelajaran khususnya dalam pembelajaran bahasa Jepang.

Beberapa masalah yang timbul dalam pembelajaran bahasa Jepang seperti belum semua pengajar menggunakan pendekatan saintifik yang berfokus dan bermuara pada peserta didik. Sehingga ada beberapa masalah yang timbul khususnya dalam pembelajaran bahasa Jepang baik pada lembaga maupun pendidikan formal dan non formal yang dapat menghambat kegiatan belajar dan menanamkan kemampuan berbahasa Jepang. Permasalahan tersebut salah satunya adalah kendala yang berhubungan dengan kurikulum dan bahan ajar. Hal ini membuat pengajar harus ekstra dalam memikirkan bagaimana cara agar pengajar di dalam kelas tidak hanya sekedar mentransfer ilmu saja, tetapi pengajar harus menjadikan peserta didik terlibat banyak atau aktif di dalam proses pembelajaran.

Dalam pembelajaran bahasa khususnya bahasa Jepang keterampilan seorang pengajar sangat diperlukan supaya peserta didik termotivasi dalam proses pembelajaran. Apabila pengajar dapat menguasai keterampilan mengajar dengan baik maka siswa akan menjadi semangat dalam menerima materi yang disampaikan. Setiap pengajar dalam satuan pendidikan mempunyai kewajiban untuk memberikan arahan sehingga proses belajar mengajar berlangsung dengan menyenangkan dan siswa termotivasi untuk berpartisipasi aktif (Said, 2016). Oleh karena itu, penting juga halnya bagi mahasiswa PPL Real sebagai pengajar untuk memahami landasan dalam mengembangkan keterampilan mengajar.

Sebagai studi pendahuluan, telah dilakukan wawancara pada tanggal 30 Oktober 2018 terhadap 10 orang mahasiswa PPL Real Jurusan Pendidikan Bahasa Jepang Tahun 2018 mengenai pelaksanaan keterampilan mengajar berdasarkan pendekatan saintifik saat praktik mengajar di kelas. Dari hasil wawancara didapatkan bahwa mahasiswa masih mengalami beberapa kesulitan. Pertama, dalam mengembangkan keterampilan berdasarkan pendekatan saintifik terutamanya dalam bagian mengasosiasi yaitu mengolah informasi yang sudah dikumpulkan dari hasil kegiatan mengamati dan mengumpulkan informasi.

Kedua pada bagian mengkomunikasikan yaitu penyampaian hasil pengamatan siswa. Pada bagian ini mahasiswa PPL sulit mengelola kelas dan belum menerapkan metode atau keterampilan agar siswa bisa mengkomunikasikan dengan baik, sehingga siswa kurang kondusif dan terdapat siswa yang bisa menyampaikan namun tidak memahami makna yang disampaikan. 
Ketiga pada tahap mengamati yaitu seharusnya kegiatan yang dilakukan dengan memaksimalkan panca indera dengan cara melihat, mendengar, membaca, menyentuh atau menyimak. Tetapi sesekali mahasiswa masih menggunakan sistem ceramah untuk menjelaskan materi karena berpatokan terhadap guru pamong dan juga karena siswa belum terbiasa menggunakan tahap ini.

Dari hasil wawancara ke 10 mahasiswa pelatihan PPL Real tahun 2018, penulis mengambil kesimpulan mereka mengalami problematika dalam pengembangan keterampilan bahasa Jepang. Sehingga berdasarkan uraian diatas, maka timbul keinginan untuk meneliti problematika yang dihadapi dalam pengembangan keterampilan mengajar berbasis penerapan saintifik pada mahasiswa PPL Real Tahun 2018 Jurusan Bahasa Jepang.

Penelitian terkait keterampilan mengajar telah dilaksanakan oleh beberapa peneliti salah satunya adalah Khoirunnisa (2016). Khoirunnisa (2016) melakukan penelitian tentang kesulitan mahasiswa praktikan dalam melaksanakan latihan penerapan atau ouyou renshuu. Penelitian ini memfokuskan kepada kesulitan yang dihadapi mahasiswa PPL dan faktor penyebab kesulitan tersebut. Selain itu Wari (2016) juga melakukan penelitian mengenai kesulitan yang dihadapi oleh mahasiswa PPL namun menfokuskan kepada kesulitan dalam menyusun RPP sesuai dengan kurikulum 2013. Permasalahan yang akan dibahas dalam penelitian ini yaitu problematika yang dihadapi dalam pengembangan keterampilan mengajar dengan pendekatan saintifik pada mahasiswa pelatihan PPL Real Tahun 2018 Jurusan Bahasa Jepang Undiksha.

\section{Metode}

Pendekatan yang digunakan dalam penelitian ini adalah dengan pendekatan deskriptif kualititatif. Dalam hal ini peneliti mengumpulkan data berupa angket untuk mengetahui problematika yang dihadapi oleh mahasiswa PPL Real dalam pengembangan ketrampilan berdasarkan pendekatan saintifik.

Pengumpulan data melalui kuesioner akan dianalisis, dipersentasekan dan dideskripsikan secara kualititatif. Selanjutnya data yang diperoleh melalui wawancara akan dideskripsikan secara kualitatif.

\section{Reduksi Data(Data Reduction)}

Reduksi data merupakan proses memilih hal-hal atau data pokok, merangkum dan memfokuskan pada hal-hal yang penting. Proses ini berlangsung selama penelitian ini dilakukan, dari awal sampai akhir penelitian.

Reduksi data dilakukan dengan penyederhanaan data yang diperoleh dari hasil kuesioner dan wawancara dari responden mengenai problematika yang dihadapi pada pengembangan keterampilan berdasarkan pendekatan saintifik oleh mahasiswa PPL Real.

\section{Penyajian Data (Data Display)}

Langkah kedua dalam teknik analisis data dalam penelitian ini yaitu menyajikan data. Penyajian data merupakan proses menyusun informasi atau data untuk memudahkan dalam memahami dan menganalisis data sehingga memberi kemungkinan untuk menarik kesimpulan dan pengambilan tindakan.

Bentuk penyajian data dalam penelitian ini ialah berupa tabulasi data, yaitu data yang diproleh akan disajikan kedalam bentuk tabel dan dipersentasekan, kemudian akan dijelaskan ke dalam bentuk teks deskriptif untuk memudahkan membaca data dan menarik kesimpulan.

\section{Penarikan Kesimpulan atau Verifikasi (Conclusion Drawing/Verification)}

Proses penarikan kesimpulan akan dilakukan jika seluruh data dari kuesioner dan wawancara telah terkumpul dan tersusun berdasarkan kategori tertentu.Kesimpulan dalam penelitian kualitatif merupakan jawaban dari segala permasalahan penelitian dan temuan baru yang dapat berupa deskripsi atau gambaran suatu objek yang sebelumnya masih belum jelas sehingga setelah diteliti menjadi jelas. 


\section{Hasil dan Pembahasan}

Kesulitan dalam mengembangkan keterampilan dalam aspek mengamati

Berdasarkan hasil kuesioner dan wawancara yang telah dilakukan diketahui bahwa mahasiswa PPL Real Bahasa Jepang mengalami kesulitan dalam mempersiapkan tempat objek yang digunakan dalam proses mengamati dan kesulitan dalam memberikan acuan yang menantang untuk berpikir pada peserta didik.

1. Kesulitan dalam mempersiapkan objek yang digunakan dalam proses mengamati.

Dari hasil wawancara diketahui bahwa mahasiswa PPL Real diketahui bahwa mahasiswa cenderung mengalami kesulitan dalam mempersiapkan objek yang diamati. Hal ini mempengaruhi pengembangan keterampilan mahasiswa dalam prakter mengajar sehingga pembelajaran belum terlaksana dengan baik.

Kendala pertama yang dihadapi oleh mahasiswa PPL Real adalah kesulitan pada media yang digunakan yaitu berupa LCD. Mahasiswa sering menggunakan LCD untuk membantu proses mengamati misalnya dalam menampilkan gambar, kosakata dan lain lain. Namun tidak semua LCD yang difasilitasi sekolah bisa berfungsi dengan baik, terdapat beberapa responden mengatakan seringkali terjadi gangguan LCD ketika akan mengajar, sehingga menghambat terjadinya proses pembelajaran dan membuat siswa tidak konsentrasi. Selanjutnya ketika menggunakan fasilitas lainnya yang ada di sekolah seperti e kado mahasiswa mengalami kesulitan karena gambarnya sudaah tidak lengkap dan gambarnya sudah lama.

Karena hal-hal tersebut mahasiswa mengatasi dengan membuat media sendiri dengan cara mencetak gambar yang disesuaikan dengan materi yang akan diajarkan di internet, namun mahasiswa tidak bisa sering mengatasi dengan hal tersebut karena memerlukan dana dan biasanya dana tersebut dikeluarkan oleh mahasiswa praktikkan sendiri.

2. Kesulitan dalam memberikan acuan yang menantang peserta didik untuk berpikir

Berdasarkan hasil wawancara diketahui bahwa 9 dari 10 mahasiswa PPL Real yang menjadi responden wawancara mengalami kesulitan dalam memberikan acuan yang menantang kepada peserta didik. Responden mengatakan kesulitan untuk membuat siswa benar - benar fokus dalam aspek mengamati seperti mengamati gambar, kosakata baru, dan lain lain. Dan siswa juga tidak pernah mengamati secara serius karena kebanyakan siswa tidak paham dengan apa yang dijelaskan sehingga terdapat siswa yang tidak berminat dan kurang antusias dalam pembelajaran.

Kesulitan dalam pemilihan kegiatan yang tepat yaitu sesuai dengan kemampuan siswa, menarik dan sejalan dengan materi pembelajaran penyebabnya dikarenakan pemahaman pengajar yang kurang dalam pemilihan variasi pembelajaran yang menarik dan tetap sesuai dengan kurikulum 2013.

Kesulitan dalam mengembangkan keterampilan dalam aspek menanya

Berdasarkan hasil kuesioner dan wawancara yang telah dilakukan diketahui bahwa mahasiswa PPL Real Bahasa Jepang mengalami kesulitan dalam mendorong atau menginspirasi peserta didik untuk aktif, merangsang adanya diskusi dan mengingatkan peranan siswa sebagai subjek belajar.

1. Kesulitan dalam mendorong peserta didik untuk aktif

namun menurut responden hal ini masih sulit disebabkan oleh siswa sendiri, siswa malu bertanya ketika belum mengerti sehingga keaktifan masih didominasi oleh pengajar yang bertanya kepada siswanya. Siswa juga terkadang tidak menjawab ketika ditanya sudah mengerti atau belum seakan - akan sudah mengerti tetapi siswa belum paham dengan apa yang dijelaskan sehingga susah mendorong siswa agar bisa aktif dalam pembelajaran.

Kesulitan kedua adalah minat siswa dalam mempelajari bahasa Jepang yang kurang karena bahasa Jepang merupakan bahasa asing yang memiliki karakteristik baik dari tulisan maupun bacaan yang mengharuskan siswa untuk berupaya sedikit keras dalam 
mempelajarinya. Hal ini membuat siswa pasif dalam pembelajaran dan lebih memilih berbicara dengan teman sebangkunya.

2. Kesulitan dalam merangsang adanya diskusi dan mengingatkan peranan siswa sebagai subjek belajar

Kegiatan ini menimbulkan aktivitas mental dan emosional peserta didik. Tetapi, dalam diskusi sering dijumpai peserta didik mengobrol tentang hal - hal diluar pembelajaran dan sesuai dengan hasil wawancara hal ini sering dihadapi oleh responden. Hal ini disebabkan oleh beberapa hal seperti kondisi kelas yang gemuk dan minat siswa dari dalam diri yang kurang sehingga siswa kurang aktif menanggapi dan kurangnya pengajar sendiri dalam menciptakan pembelajaran yang menarik minat belajar siswa. Penyebab lainnya adalah siswa takut salah dalam memberikan gagasan atau ide idenya sehingga lebih memilih menganggu temannya.

Kesulitan dalam mengembangkan keterampilan dalam aspek mengumpulkan informasi

Berdasarkan hasil kuesioner dan wawancara yang telah dilakukan diketahui bahwa mahasiswa PPL Real Bahasa Jepang mengalami kesulitan dalam menerapkan metode intruksi singkat dan jelas disertai contoh atau simulasi tanpa menerapkan metode ceramah dan menerapkan kegiatan pembelajaran yang berorientasi pada hasil yang bisa diukur dan diamati.

1. Kesulitan dalam menerapkan metode intruksi yang singkat dan jelas.

Pertama pada Kurikulum 2013, pengajar dituntut untuk mengurangi metode ceramah dan memberikan kesempatan untuk siswa agar berpikir secara mandiri, namun kenyataannya di lapangan sesuai dengan hasil wawancara dengan responden mengatakan bahwa hal tersebut masih sulit dilaksanakan karena menambah kebingungan siswa tersebut. Sehingga pengajar harus menerapkan kembali metode ceramah agar siswa lebih paham dalam proses pembelajaran.

2. Kesulitan dalam menerapkan kegiatan pembelajaran yang berorientasi pada hasil yang bisa diukur.

Pada tahap ini hasil belajar akan lebih diingat dalam memori peserta didik, apabila mereka diberi kesempatan mencoba atau diberikan kegiatan yang bisa diukur hasilnya. Kegiatan mencoba dapat diwujudkan dalam bentuk kegiatan seperti peserta didik diminta untuk membuat contoh pola kalimat, diminta untuk menyebutkan kosakata kembali. Namun, akibat perbedaan karakter siswa dan waktu hal tersebut tidak bisa dijalankan dengan sempurna.

Menurut hasil wawancara, mahasiswa PPL Real mengalami kesulitan ketika banyak siswa yang belum memahami materi yang sudah disampaikan dan malu bertanya sebelumnya sehingga pada tahap mencoba banyak siswa yang salah dan mahasiswa harus mengulang kembali materi agar siswa memahami betul apa yang disampaikan. Hal tersebut juga mempengaruhi waktu yang dialokasikan dan mahasiswa juga terkadang menghentikan kegiatan walaupun masih terdapat siswa yang belum mengerti karena masih banyak kegiatan berikutnya yang harus dilaksanakan sebagai gantinya terkadang mahasiswa meminta kembali siswa yang belum paham untuk membuat contoh pada saat kegiatan mengkomunikasikan.

Kesulitan dalam mengembangkan keterampilan dalam aspek menalar/ mengasosiasi

Berdasarkan hasil kuesioner dan wawancara yang telah dilakukan diketahui bahwa mahasiswa PPL Real Bahasa Jepang mengalami kesulitan yang dihadapin dalam memfasilitasi peserta didik untuk melakukan proses menalar atau mengasosiasi, kesulitan yang dihadapi dalam menggunakan kombinasi pola interaksi pembelajaran lebih aktif, kesulitan yang dihadapi dalam mengontrol waktu dalam aspek menalar atau mengasosiasi.

1. Kesulitan dalam memfasilitasi peserta didik untuk melakukan proses menalar atau mengasosiasi 
Menurut hasil wawancara, kegiatan yang seharyusnya dilaksanakan pada tahap ini adalah memasukkan unsur budaya atau membandingkan budaya Jepang dan Indonesia. Namun, kendalanya mahasiwa PPL Real masih belum memahami secara penuh budaya budaya yang bisa digunakan dan kesulitan dalam menentukkan budaya yang sesuai dengan materi yang dijelaskan. Mahasiswa PPL Real kurang mampu untuk memunculkan perbandingan budaya Jepang dan budaya sekitar siswa sehingga dalam memfasilitasi peserta didik untuk melakukan proses menalar atau mengasosiasi sering dilewati oleh mahasiswa PPL Real.

2. Kesulitan dalam menggunakan kombinasi pada interaksi pembelajaran agar lebih aktif

Berkaitan dengan menggunakan kombinasi pada interaksi agar pembelajaran lebih aktif, menurut hasil wawancara mahasiswa mengalami kesulitan karena kurang pahamnya terhadap unsur budaya yang harus diberikan pada tahap menalar sehingga mempengaruhi interaksi pembelajaran menjadi monoton tanpa adanya kombinasi.

Kesulitan dalam mengembangkan keterampilan dalam aspek mengkomunikasikan

Berdasarkan hasil kuesioner dan wawancara yang telah dilakukan diketahui bahwa mahasiswa PPL Real Bahasa Jepang mengalami kesulitan yang dihadapi dalam memberikan klarifikasi agar peserta didik dapat mengetahui dengan tepat kebenaran dan perbaikan mengenai hal yang sudah dikerjakan dan kesulitan yang dihadapi dalam mengontrol waktu dalam aspek mengkomunikasikan.

1. Kesulitan yang dihadapi dalam memberikan klarifikasi pada peserta didik

Pada tahap ini, peserta didik memamparkan hasil pemahamannya terhadap sesuatu konsep atau bahasan secara lisan atau tertulis. kegiatan yang dapat dilakukan adalah melakukan presentasi laporan hasil percobaan, mempresentasikan peta konsep dan lain lain lalu pengajar bertugas untuk memberikan klarifikasi terhadap hasil yang sudah dipaparkan oleh siswa.

Menurut hasil wawancara, responden mengalami kesulitan dalam memberikan respon dengan ungkapan yang tepat agar siswa lebih mengerti dengan klarifikasi yang diberikan dan setelah di klarifikasi siswa lain mengulang kembali kesalahan yang sama hal ini menandakan bahwa siswa tidak mendengarkan pengajar saat memberikan klarifikasi terhadap siswa lainnya.

2. Kesulitan dalam mengontrol waktu dalam aspek mengkomunikasikan

Dalam pembelajaran bahasa tahap mengkomunikasikan dapat diwujudkan dengan berbagai cara seperti dengan latihan percakapan ke depan kelas, dengan memberikan games, membuat wacana singkat, dan lain sebagainya. Berdasarkan wawancara yang dilakukan, dapat diketahui bahwa pelaksanaan tahap mengkomunikasikan dilakukan dengan bermain peran (role play), bermain game, interview, melafalkan dan membaca wacana yang ada dibuku. Tetapi, mahasiswa PPL Real mengalami kesulitan dalam pelaksanaannya sehingga tahap ini tidak terlaksana sesuai dengan alokasi waktu yang sudah direncanakan.

Hal ini disebabkan oleh beberapa faktor seperti kelas yang gemuk dan banyak yang belum paham terhadap materi sehingga perlu diulang - ulang dalam melakukan kegiatan dan memberikan klarifikasi dan hal tersebut mempengaruhi waktu yang digunakan. Adanya perbedaan kemampuan siswa juga mempengaruhi pelaksanaan tahap ini, pengajar harus memberikan waktu tambahan karena siswa tidak bisa mengerjakan sesuai waktu yang diberikan sehingga tidak semua siswa mendapat kesempatan untuk memaparkan hasilnya terutama pada saat menggunakan kegiatan bermain peran atau role play.

\section{Simpulan dan Saran}

Berdasarkan rumusan masalah, hasil penelitian dan pembahasan maka dapat ditarik simpulan bahwa mahasiswa PPL Real mengalami kesulitan dalam melaksanakan pengembangan keterampilan berbasis pendekatan saintifik seperti pada aspek mengamati, menanya, mencoba, mengasosiasi dan mengkomunikasikan. Mahasiswa PPL Real Jurusan 
Pendidikan Bahasa Jepang Undiksha Tahun 2018 mengalami problematika pada saat pelaksanaan mengembangkan keterampilan mengajar berbasis pendekatan saintifik seperti mengamati, menanya, mencoba, mengasosiasi dan mengkomunikasikan. Penelitian ini menunjukkan bahwa kesulitan yang dihadapi mahasiswa PPL Real dalam pelaksanaan pengembangan keterampilan mengajar pada aspek mengamati yaitu mempersiapkan objek yang digunakan dalam proses mengamati dan memberikan acuan yang menantang kepada peserta didik. Kesulitan pada aspek menanya yaitu mendorong dan menginspirasi peserta didik agar aktif dan merangsang terjadinya diskusi. Kesulitan pada aspek mencoba yaitu menerapkan metode intruksi disertai contoh dan simulasi tanpa metode ceramah berlebihan dan menerapkan kegiatan pembelajaran yang berorientasi pada hasil yang bisa diukur dan diamati. Kesulitan pada aspek mengasosiasi yaitu memfasilitasi peserta didik untuk melakukan proses mengasosiasi dan mengontrol waktu dalam aspek mengasosiasi. Selanjutnya kesulitan pada aspek mengkomunikasikan yaitu memberikan klarifikasi agar peserta didik dapat mengetahui dengan tepat kebenaran dan perbaikan mengenai hal yang sudah dikerjakan dan mengontrol waktu dalam aspek megkomunikasikan.

\section{Daftar Pustaka}

Kemendikbud. 2016. "Empat Perbaikan Kurikulum 2013". JENDELA, Volume 3, Edisi Khusus (hlm.6-21).

Mulyasa.2013. Pengembangan dan Implementasi Kurikulum 2013. Bandung : PT Remaja Rosdakarya.

Permatasari, Eka Aprilia. 2014. "Implementasi Pendekatan Saintifik Dalam Kurikulum 2013 Pada Pembelajaran Sejarah". Indonesian Journal Of History Education, Vol. 3, No.1, ISSN : $2252-6641$.

Said, Isa.M. 2016 "The Scientific Approach-Based Cooperative Learning Tool for Vocational Students Vocation Program of Autotronic (Automotive Electronic) Engineering". IOSR Journal of Research and Method in Education.Vol. 6, No.3. E-ISSN : 2320-7388.

Zaim, M. 2017 "Implementing Scientific Approach to Teach English at Senior High Shcool in Indonesia". Asian Sosial Science. Vol.13, No.2, E-ISSN : 1911 - 2025. 